WORKING PAPER 1/2019

THE CURRENCY COMPOSITION OF INTERNATIONAL PORTFOLIO ASSETS

\title{
Vahagn Galstyan
}

Caroline Mehigan

and

Rogelio V. Mercado, Jr.

The South East Asian Central Banks (SEACEN) Research and Training Centre (80416-M) Kuala Lumpur, Malaysia 
WORKING PAPER 1/2019

THE CURRENCY COMPOSITION OF INTERNATIONAL PORTFOLIO ASSETS

Vahagn Galstyan*

Caroline Mehigan**

and

Rogelio V. Mercado, Jr.***

January 2019

* Trinity College Dublin, Email: v.galstyan@tcd.ie

** Organisation for Economic Co-Operation and Development, Email: caroline.mehigan@oecd.org *** The SEACEN Centre, Email: rogelio.mercado@seacen.org.

The views expressed in this paper are those of the authors alone and do not reflect the official views of the Organisation for Economic Co-Operation and Development, and the South East Asian Central Banks Research and Training Centre (The SEACEN Centre). 


\begin{abstract}
In this paper, we empirically assess the importance of gravity-type variables and measures of macroeconomic and financial volatilities in explaining portfolio holdings denominated across the main global currencies: US dollar (USD), euro (EUR), Pound sterling (GBP), Japanese yen (JPY) and Swiss franc (CHF). Our findings underscore the importance of trade ties and membership of the euro area. We also find that international positions co-move with the level of macroeconomic and financial uncertainty. Importantly, we identify heterogeneous patterns at a currency level.
\end{abstract}

Keywords: $\quad$ Currency Composition, International Portfolio Assets, Trade, Volatility

JEL Classification: F31, F36, F41, G15

Disclaimer: This Working Paper should not be reported as representing the views of SEACEN or its member central banks/monetary authorities. The views expressed in this Working Paper are those of the author(s) and do not necessarily represent those of SEACEN or its member central banks/monetary authorities. 
Abstract

1. Introduction 1

2. Empirical Specification 2

3. Data 3

3.1 Variables and Sources 3

3.2 Stylised Facts 4

4. Empirical Results 5

5. Conclusion 8

$\begin{array}{ll}\text { References } & 9\end{array}$

Figures and Tables

Figure 2: Portfolio Holdings $\quad 10$

Table 1: Portfolio Asset Shares 11

Table 2: Currency Shares by Assets $\quad 12$

Table 3: Equity Regressions: Advanced Sample 13

Table 4: Equity Regressions: Emerging Sample $\quad 14$

Table 5: Debt Regressions: Advanced Sample $\quad 15$

Table 6: Debt Regressions: Emerging Sample 16

Appendix: Sample of Countries $\quad 17$ 


\section{THE CURRENCY COMPOSITION OF INTERNATIONAL PORTFOLIO ASSETS}

By

Vahagn Galstyan, Caroline Mehigan and Rogelio V. Mercado, Jr.

\section{Introduction}

The analysis of patterns, composition and currency of denomination of international investments is of paramount importance for our understanding of the transmission of external shocks and the extent of international risk sharing. Yet, empirical analysis of this type has not been fully possible due to a lack of detailed data on international asset positions across a range of countries and over time. In response, the G20 data gaps initiative has been initiated, aiming to provide more detailed data at the country level. The Coordinated Portfolio Investment Survey (CPIS), published by the International Monetary Fund, has played a large part in this endeavour, and now it provides portfolio data disaggregated by sectors and the currency of denomination. Our objective in this paper is to empirically assess the importance of gravity-type variables and measures of macroeconomic and financial volatilities in explaining portfolio holdings denominated across the main global currencies: US dollar (USD), euro (EUR), Pound sterling (GBP), Japanese yen (JPY) and Swiss franc (CHF).

There are many studies examining patterns in the aggregate international portfolio holdings and investments of countries (Aviat and Coeurdacier, 2007; Daude and Fratzscher, 2008; Galstyan and Lane, 2013; Lane and Milesi-Ferretti, 2008; Portes and Rey, 2005; Stein and Daude, 2007). Adopting a gravity-style framework, this literature highlights the importance of bilateral ties and institutions in shaping cross-border distribution of international portfolio investments. More recent studies take a granular approach on portfolio holdings (Avdjiev et al., 2017; Galstyan et al., 2016; Galstyan and Velic, 2017). They show that the relationships present in aggregate data are not indicative of the underlying sectoral relationships.

Turning to foreign currency exposure, volatilities of inflation, exchange rates and asset returns seem to explain cross-country variation of external positions (Benetrix et al., 2015; Benetrix and Lane, 2016; Lane and Shambaugh, 2010). These volatilities tend to exacerbate risks associated with foreign investment exposures (Lane, 2013). Building on this extensive research, we investigate whether the covariates identified in the literature that shape crossborder portfolio allocation exhibit differential patterns by the currency of denomination.

Our approach is similar to the work of Benetrix and Lane (2016). Unlike these authors, however, we exploit CPIS data that disaggregates international portfolio equity and long-term debt holdings by the major currencies in order to study the importance of economic ties and 
macro-financial volatilities in explaining international portfolio holdings by currency of denomination. Previewing our results, we find that the currency bias (Burger et al., 2017) is prevalent in the case of US dollar and euro denominated holdings only. Since the Global Financial Crisis in the sample of emerging economies, we observe a gradual decline of holdings in major currencies and an increase of holdings in the 'other-currencies' category, a pattern that signifies an important development in this group of countries such as the increased willingness of investors to hold assets denominated in local currency.

The findings also highlight the importance of gravity-type factors. For instance, imports from the country with the reference currency are associated with longer positions in the reference currency, capturing the hedging of currency risk. Membership of the euro area is also non-negligible in explaining the differences in portfolio holdings across major currencies. Finally, we find that international positions co-vary with the level of macroeconomic and financial uncertainty. Resembling the general conclusions of Galstyan et al. (2016) and Galstyan and Velic (2017), we identify heterogeneous patterns at a currency level.

The rest of the paper is structured as follows. Section 2 outlines the empirical specification, while Section 3 provides an overview of the data. In Section 4, we discuss the econometric results. Finally, Section 5 provides concluding remarks.

\section{Empirical Specification}

The objective of the paper is to assess the determinants of international portfolio assets denominated in various currencies. Accordingly, we analyze international asset positions by estimating the following specification:

$$
\ln \left(A_{i, t}^{j}\right)=\theta^{\prime} x_{i, t-1}+\varepsilon_{i t}
$$

where $\ln \left(A_{i t}^{i_{i t}}\right)$ is the natural logarithm of the outstanding equity or debt (long-term) position by reporting country i denominated in currency $\mathrm{j} \in$ (USD, EUR, GBP, JPY, CHF) in year $t$, and $x_{i t}$ is a row vector of controls with $\theta$ column vector of coefficients.

With our regressors we aim to capture economic ties between countries in the context of gravity-type regressions on portfolio holdings, as well as the macroeconomic and financial volatilities in relation to the risk exposures and their impact on valuation effects and stock-flow adjustments of international balance sheets. To this end, in line with the covariates highlighted by the literature, our vector of controls includes the log of imports of country $i$ at time $t$ from the country with the reference currency to proxy for bilateral information flows, domestic credit as a share of GDP, five year rolling volatility of inflation and the annual volatility of weekly nominal exchange rate changes. 
We also consider various measures of uncertainty in financial markets as well as correlations across equity returns and bond yields as these tend to influence asset holdings in incomplete markets environment. Thus, for equity regressions, the vector of controls also includes the annual volatility of end-of-week equity returns, and the annual correlation of weekly equity returns between country i and the country of reference currency. ${ }^{1}$ In relation to debt regressions, the controls also include the annual volatility of end-of-week long-term bond yields and the annual correlation of weekly yields between country $i$ and the country of reference currency. In all specifications, we use lagged regressors. ${ }^{2}$ Finally, we include an EURO dummy that takes the value 1 if the holding country is a member of euro area and 0 otherwise, as well as the log of per capita GDP and the log of aggregate holdings in each asset class at the beginning of period t. Equation (1) is estimated with pooled OLS for both advanced and emerging country samples, after controlling for global shifts captured by timefixed effects.

\section{Data}

\subsection{Variables and Sources}

Since 2001, the International Monetary Fund has on a regular basis published the Coordinated Portfolio Investment Survey (CPIS). Relative to aggregate international investment position data, the CPIS describes the geographical composition of cross-border asset holdings of the reporting countries. Since 2013, an expanded version of the CPIS reports the currency composition of international asset holdings broken down between US dollars, euro, Japanese yen, Swiss francs, Pound sterling and a catch-all "Other" category. ${ }^{3}$ These data (measured in USD) are available for both equity and debt categories for a range of advanced and emerging countries for years 2001 to 2015 .

Bilateral imports, used to construct aggregate imports of country I at time t from the country with the reference currency, are sourced from the IMF's Direction of Trade Statistics. Data on domestic credit provided by the financial sector to the private sector as a share of GDP, as well as per capita GDP in constant 2010 dollars are from the World Bank's World Development Indicators. We use the annual change in consumer price index from the IMF's World Economic Outlook to measure the volatility of inflation constructed by a five-year standard deviation on a rolling basis.

Finally, weekly data on foreign exchange, stock price indices, and long-term bond yields are sourced from Datastream. These are used to construct the annual volatility of log changes in weekly bilateral exchange rates with the country of the reference currency, the annual volatility of weekly equity returns, the annual correlation of weekly equity returns

\footnotetext{
We measure equity returns as log changes in weekly domestic equity price indices.

The results are very similar with contemporaneous regressors.

At the time of writing, the currency breakdown is not available on a bilateral basis.
} 
between country $\mathrm{i}$ and the country of the reference currency, the annual volatility of weekly long-term bond yields and the annual correlation of weekly yields between country $i$ and the country of the reference currency.

Our final dataset results in a sample broadly containing 44 countries over the period 2001 to 2015, 15 of which are advanced and 29 are emerging. ${ }^{4}$ We have chosen to remove offshore financial centres from the dataset given their significant role in intermediating international investments (Lane and Milesi-Ferretti, 2011).

\subsection{Stylised Facts}

The CPIS data allows us to discern certain cross-sectional patterns for various currencies and country groups across time and asset types. For instance, to get a sense of the currency bias (Burger et al., 2017), Figure 1 presents the shares of foreign portfolio assets denominated in local currency relative to the corresponding totals for the US, euro area, Japan, and Switzerland in $2015 .^{5}$ The figure shows that approximately three quarters of US debt holdings are denominated in US dollars, highlighting the reserve-currency status of the dollar. For the euro area, the holdings of euro-denominated equities, long-term debt and shortterm debt account for 57, 84 and 66 percent of the corresponding totals, a pattern explained by substantial financial trade among countries of the euro area (Lane, 2006). These shares are in stark contrast to those of Japan and Switzerland, where foreign assets denominated in local currency account for substantially less than half of the corresponding totals.

For a given asset type, Figure 2 shows the ratio of portfolio asset holdings in a given currency by the rest of the world relative to the liabilities of the country with the reference currency. ${ }^{6} \mathrm{~A}$ value greater than one, highlights the extent to which other countries issue foreign currency denominated liabilities. The ratios are significantly larger than one for US dollar denominated long-term debt (at 2.15) and short-term debt (at a massive 5.45) as well as Japanese yen denominated long-term debt (at 4.05) holdings. The ratios are marginally greater than one for euro denominated holdings and are lower than one for holdings denominated in Swiss francs and Pound sterling. This pattern again highlights the special status of US dollar as the international reserve currency.

Table 1 presents the shares of portfolio assets as percentage of the corresponding total holdings by asset type and country group. We note that most portfolio assets are held in a form of either equity or long-term debt in the samples of advanced and emerging economies. In the advanced sample, we observe a significant rebalancing from debt assets into equity

4 The number of countries varies by currency-asset pair. See the Appendix for a detailed list of countries.

5 The US does not report currency breakdown of equity holdings, while the UK does not report currency breakdown on any of foreign portfolio assets.

6 These are authors' calculations based on the CPIS data, and not officially reported aggregate world holdings. 
assets after year 2008. Specifically, the share of debt assets in total holdings declined to less than 50 percent in 2015 from over 65 percent in 2008. In contrast, in the sample of emerging economies, shares of both equity and debt have experienced smaller shifts. This shift from debt to equity reflects the normalization of trading following the flight for safety during the crisis period, as well as the search for yield during times of ultra-low interest rates as investors aim to improve aggregate portfolio returns.

In Table 2, we further decompose portfolio asset shares by currency for the two country groups. A snap-shot of 2015 highlights substantial variation in the currency shares across advanced and emerging economies. In the advanced sample the currency share is highest for the euro: the share of euro denominated equity holdings stands at 44 percent, while the share of euro denominated long-term debt holdings stands at 54 percent. The US dollar is in second place (with shares of US dollar denominated equity and long-term debt standing at 27 and 33 percent correspondingly), followed by 'other-currencies' (with shares of equity and long-term debt standing at 14 and 6 percent correspondingly). Finally, while the share of short-term debt in total holdings is very small (3 percent), the split between currencies favours US dollars (48 percent) followed by euro (32 percent) and Japanese yen (12 percent). We also observe significant shifts in shares from US dollars to euro during the 2004-2008 period and back to US dollar during the 2008-2015 period, a pattern that reflects both compositional shifts and valuation effects. $^{7}$

In line with the importance of US dollars in determining the market conditions in developing economies, the dollar is the dominant currency across all asset types with shares of US dollar denominated equity, long-term and short-term debt standing at 54, 70 and 86 percent. A notable feature for the group is the 'other-currencies' category that occupies the second place in terms of currency shares. These shares exhibited bell shaped dynamics during pre-crisis, crisis and post-crisis periods, peaking in 2008 at 38, 16 and 28 percent for equity, long-term and short-term debt, gradually declining afterwards to stand at 27, 13 and 6 percent in 2015. Overall, this pattern signifies an important development in emerging economies highlighting the increased willingness of local investors to hold assets denominated in local currency.

\section{Empirical Results}

Tables 3 and 4 present the results for equity holdings of advanced and emerging economies respectively. ${ }^{8}$ For both sample splits, imports from the reference country are positively and significantly correlated with equity holdings denominated in the reference currency, with the exception of holdings in Pound sterling and Japanese yen for advanced

The Euro appreciated against the US dollar from 1.36 (end of December 2004) to 1.39 (end of December 2008) with substantial volatility during 2008 crisis, depreciating to 1.08 by the end of December 2015.

8 We do not report results for short-term portfolio debt as they account for less than 5 percent of total holdings. 
countries and holdings in Japanese yen and Swiss franc for emerging countries. The positive coefficient captures the hedging of currency risk (Obstfeld and Rogoff 2001). Turning to credit in the sample of advanced countries, the coefficient is positive and significant in the case of Japanese yen and Swiss franc denominated equity holdings, negative in the case of euro denominated holdings and insignificant in the case of US dollar denominated holdings. In contrast, credit is more important for US dollar holdings of emerging economies, where higher domestic credit is associated with a higher equity stock. Kharroubi and Kohlscheen (2017) find that growth driven by faster credit expansion to households appears to be less durable. As such, expectations of lower growth could be reflected in increased holdings of foreign equity.

In relation to the second order moments, higher volatility of domestic inflation is significantly positive in the case of euro and Japanese yen denominated portfolio equity holdings in the sample of advanced countries. A natural interpretation is that investors in economies with high inflation volatility seek to hold safe-haven currencies as a potential hedge against price uncertainty. ${ }^{9}$ It is striking, however, that a similar pattern is not observed for US dollar holdings. In the sample of emerging economies, the coefficient on inflation volatility is positive and statistically significant for Pound sterling denominated equity holdings only.

Turning to uncertainty in financial markets, we see that higher volatility in bilateral exchange rates is associated with shorter positions in euro equity in both samples. Uncertainty in local equity markets, measured by the standard deviation of equity returns, is negatively associated with holdings in Pound sterling (advanced countries) and euro (emerging countries). In both samples, the same volatility measure is positively associated with portfolio equity holdings denominated in Swiss francs, although to a lesser extent in emerging countries: a finding that highlights the special currency status of Swiss francs.

It is noteworthy that we find some support for the notion that reporting countries tend to invest in currencies of countries with similar domestic characteristics. The coefficient on the correlation between stock market returns is mostly positive in both samples. The coefficient, however, is statistically significant for Pound sterling denominated equity holdings of advanced economies and is marginally significant for euro and Sterling denominated holdings of emerging economies. This finding, while partly consistent with Lane and Milesi-Ferretti (2008) who report positive and statistically significant coefficients for bilateral equity holdings, also highlights the importance of the currency of denomination in explaining the implications of synchronized returns for portfolio diversification.

Finally, membership of the euro area is significantly negative for US dollar and Pound sterling denominated equities of advanced economies. Countries with higher per capita income in this group tend to hold more US dollar, Japanese yen, and Swiss franc denominated equities but significantly less euro denominated equities. In contrast, emerging economies

9 On the factors influencing holdings of Swiss francs, see also Benetrix and Lane (2016). 
with higher per capita income tend to hold more US dollar and euro denominated equities. The level of start-of-year total equity holdings is included as a 'catch everything else' scaling factor: as expected, it is positive and significant in all specifications.

We conduct a similar exercise for portfolio debt assets. The results are presented in Tables 5 and 6 . For both sample splits, trade between home and the reference country is mostly positive and significantly correlated with holdings of bonds denominated in the reference currency. The results also suggest that domestic lending co-moves negatively with holdings of US dollar and yen debt but positively with euro debt of advanced reporters, while in the sample of emerging countries, higher domestic credit is associated with higher levels of debt denominated in Pound sterling. Surprisingly, inflation volatility is negatively correlated with holdings of US dollar debt in the advanced sample. For emerging countries, the coefficient is positive for bonds denominated in Swiss francs.

Turning to variables measuring financial volatility, we see that higher volatility in bilateral exchange rate is associated with shorter positions in euro debt in both samples. Interestingly, for advanced reporters, fluctuations of currency vis-a-vis Pound sterling are positive for holdings of Sterling debt. The findings are more diverse for volatility of returns. The coefficient is negative for bonds denominated in Pound sterling and Japanese yen while positive for euro and Swiss franc denominated debt. As for the correlation between stock market returns, we find mostly positive and marginally significant coefficients with one major exception. The holdings of bonds denominated in Swiss francs are lower the higher the synchronization of returns. The finding again highlights the special currency status of Swiss Francs. ${ }^{10}$

Finally, the results suggest that member countries of the euro area tend to be long in euro and Swiss franc denominated bonds, and short in US dollar and Japanese yen denominated bonds. The results also exhibit some differences in relation to per capita income, while the coefficient on per capita GDP is significant across all currencies, bond holdings of advanced countries seem to be more biased towards Swiss francs. In the case of emerging economies, higher per capita income tends to be associated with larger positions in euro and Swiss franc denominated bonds.

Overall, our results highlight the importance of economic ties and macroeconomic and financial volatilities in determining portfolio allocation across various currencies. We also find that the relevance of macroeconomic and financial volatilities varies not only by currency but also by asset type. Importantly, we identify heterogeneous patterns at a currency level.

10 Volatility and correlation of returns are available for a small subset of emerging economies, substantially reducing the overall number of observations. Accordingly, we have decided not to use these variables in regressions pertaining to bond holdings of this group. 


\section{Conclusion}

This paper explores the distribution and determinants of international portfolio holdings denominated in various currencies. Using data from the Coordinated Portfolio Investment Survey on currency composition of international portfolio holdings, our results show that the currency bias is prevalent in the case of US dollar and euro denominated holdings only. In the sample of emerging countries, we observe a gradual decline of holdings in major currencies and an increase of holdings in the 'other-currencies' category, highlighting the increasing role of other advanced and emerging-market currencies such as the Australian dollar, Canadian dollar, and Chinese renminbi.

The findings also shed light on the relevance of gravity-type factors such that imports from the country with the reference currency are associated with longer positions in the reference currency, capturing the hedging of currency risk. Furthermore, we find that domestic price uncertainty and the risk associated with currency and asset price movements impact cross-border holdings. Importantly, the patterns that we identify are heterogeneous across currencies. The evidences provided focus on major international currencies, which are reserve currencies. Moving forward, it would be interesting to know whether "other-currencies" such as the Chinese renminbi will likewise exhibit its own heterogenous pattern across asset type.

From an empirical point of view, data on the currency composition of foreign assets can prove to be useful for macro-surveillance in understanding the distribution of macro-financial risks and propagation of international shocks. From a theoretical point of view, understanding the patterns, composition and currency of denomination of international investments can help in designing better models. As such, our findings should be of interest to both academic researchers and policymakers alike. 


\section{References}

Avdjiev, Stefan; Bryan Hardy; Sebnem Kalemli-Ozcan and Luis Serven, (2017), "Gross Capital Inflows to Banks, Corporates and Sovereigns," NBER Working Paper, No. 23116.

Aviat, Antonin and Nicolas Coeurdacier, (2007), "The Geography of Trade in Goods and Asset Holdings," Journal of International Economics, 71, pp. 22-51.

Benetrix, Agustin; Philip R. Lane and Jay Shambaugh, (2015), "International Currency Exposures, Valuation Effects and the Global Financial Crisis," Journal of International Economics, 96, pp. 98-109.

Benetrix, Agustin and Philip R. Lane, (2016), "Cross-Currency Exposures to the Swiss Franc," ESRB Working Paper, No. 6.

Burger, John; Francis Warnock and Veronica Warnock, (2017), "Currency Matters: Analyzing International Bond Portfolios," NBER Working Paper, No. 23175.

Daude, Christian and Marcel Fratzcher, (2008), "The Pecking Order of Cross-Border Investment," Journal of International Economics, 74, pp. 94-119.

Galstyan, Vahagn and Philip R. Lane, (2013), "Bilateral Portfolio Dynamics During the Global Financial Crisis," European Economic Review, 57, pp. 63-74.

Galstyan, Vahagn; Philip R. Lane; Caroline Mehigan and Rogelio Mercado, (2016), "The Holders and Issuers of International Portfolio Securities," Journal of the Japanese and International Economies, 42, pp. 100-108.

Galstyan, Vahagn and Adnan Velic, (2017), "International Investment Patterns: The Case of German Sectors," TCD Economics Papers, No. 0217.

Kharroubi, Enisse and Emanuel Kohlscheen, (2017), "Consumption-led Expansions," BIS Quarterly Review, pp. 25-37.

Lane, Philip R., (2006), "Global Bond Portfolios and EMU," International Journal of Central Banking, 2, pp. 1-23.

Lane, Philip R., (2013), "Risk Exposures in International and Sectoral Balance Sheets," First IMF Statistical Forum.

Lane, Philip R. and Gian Maria Milesi-Ferretti, (2008), "International Investment Patterns," Review of Economics and Statistics, 90, pp. 538-549.

Lane, Philip R. and Jay Shambaugh, (2010), "Financial Exchange Rates and International Currency Exposures," American Economic Review ,100, pp. 518-540.

Obstfeld, Maurice and Kenneth Rogoff, (2001), "The Six Major Puzzles in International Macroeconomics: Is there a Common Cause?" NBER Macroeconomics Annual, pp. 339-389.

Portes, Richard and Helene Rey, (2005), "The Determinants of Cross-Border Equity Flows," Journal of International Economics, 65, pp. 269-296.

Stein, Ernesto and Christian Daude, (2007), "Longitude Matters: Time Zones and the Location of Foreign Direct Investment," Journal of International Economics, 71, pp. 96-112. 
Figure 2: Portfolio Holdings

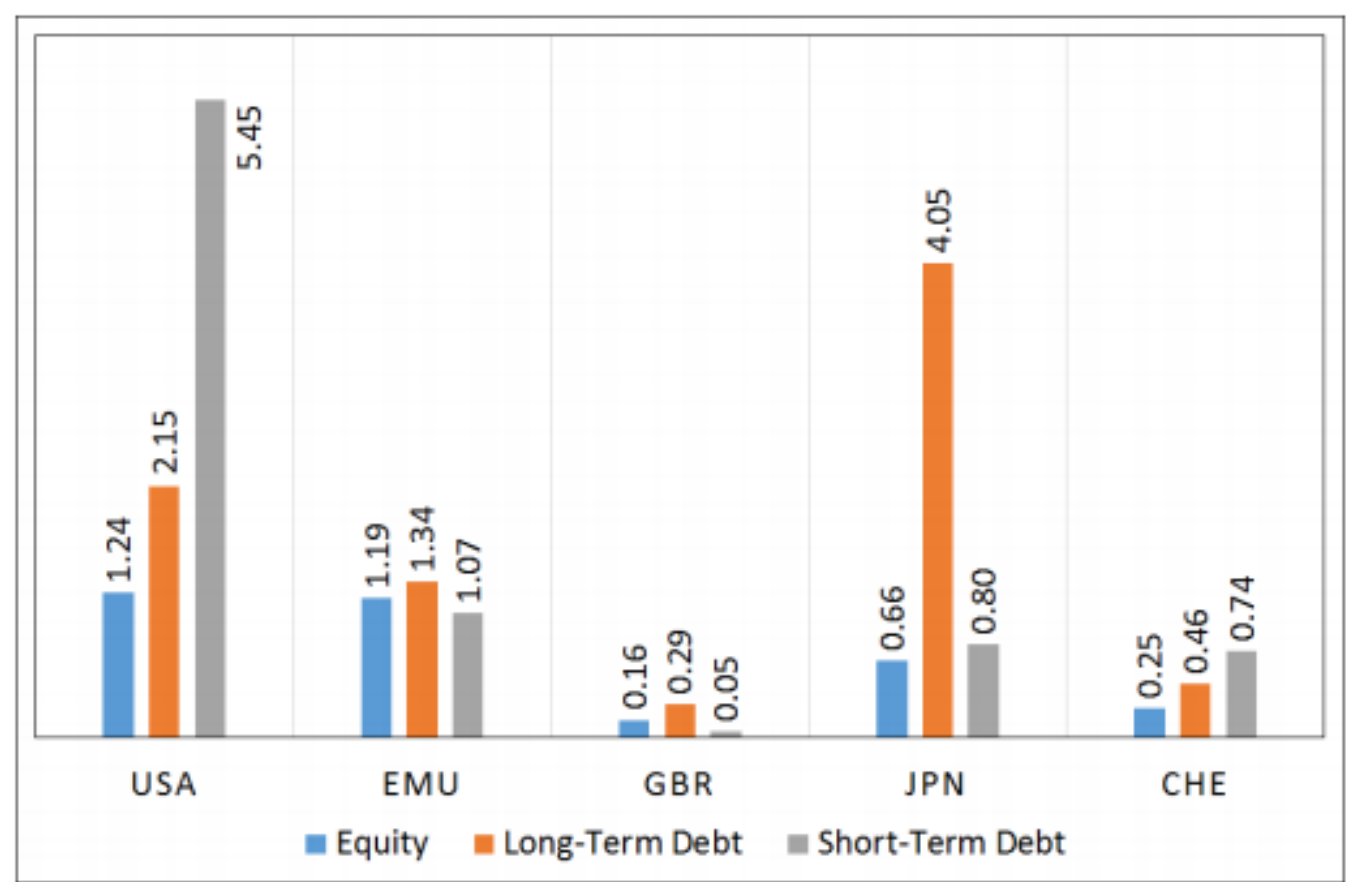

Note: The values refer to the ratio of portfolio asset holdings in a given currency by the rest of the world relative to the liabilities of the country with the reference currency. Authors' calculations based on CPIS data. 
Table 1: Portfolio Asset Shares (percent of total)

\begin{tabular}{lrrr}
\hline \hline & 2004 & $\mathbf{2 0 0 8}$ & $\mathbf{2 0 1 5}$ \\
\hline Advanced Economies & & & \\
Equity & 40.9 & 34.9 & 52.2 \\
Long-Term Debt & 55.0 & 60.4 & 44.8 \\
Short-Term Debt & 4.2 & 4.7 & 3.0 \\
Emerging Economies & & & \\
Equity & 47.6 & 49.7 & 55.0 \\
Long-Term Debt & 46.6 & 42.8 & 40.5 \\
Short-Term Debt & 5.8 & 7.5 & 4.4 \\
& & & \\
\hline \hline
\end{tabular}

Notes: The values refer to the shares of assets in total portfolio holdings (in percent). Authors' calculations based on CPIS data. Refer to the Appendix for the list of advanced and emerging countries. 
Table 2: Currency Shares by Assets (percent of total)

\begin{tabular}{lrrrrrr}
\hline \hline & & ADV & & & EM & \\
& PE & PDL & PDS & PE & PDL & PDS \\
& & & & & & \\
\hline Year 2004 & & & & & & \\
USD & 31.2 & 32.9 & 48.7 & 68.6 & 84.1 & 56.3 \\
EUR & 45.6 & 49.7 & 38.8 & 12.0 & 7.9 & 5.9 \\
GBP & 7.2 & 1.9 & 0.7 & 1.4 & 0.5 & 13.7 \\
JPY & 5.2 & 10.8 & 8.2 & 5.7 & 1.3 & 0.0 \\
CHF & 3.2 & 0.1 & 0.1 & 0.2 & 0.0 & 0.3 \\
OC & 7.6 & 4.6 & 3.5 & 12.1 & 6.2 & 23.8 \\
Year 2008 & & & & & & \\
USD & 23.2 & 24.4 & 40.6 & 48.9 & 72.3 & 61.6 \\
EUR & 57.4 & 59.7 & 42.1 & 8.8 & 9.2 & 7.6 \\
GBP & 4.6 & 2.0 & 0.4 & 1.8 & 0.9 & 2.4 \\
JPY & 4.3 & 8.8 & 15.2 & 2.0 & 1.3 & 0.2 \\
CHF & 3.1 & 0.2 & 0.0 & 0.2 & 0.0 & 0.6 \\
OC & 7.4 & 4.9 & 1.7 & 38.2 & 16.3 & 27.7 \\
Year 2015 & & & & & & \\
USD & 26.5 & 32.8 & 48.4 & 54.2 & 69.4 & 87.5 \\
EUR & 43.7 & 54.1 & 31.7 & 11.6 & 13.2 & 4.3 \\
GBP & 3.3 & 2.3 & 0.7 & 3.8 & 2.1 & 0.2 \\
JPY & 9.6 & 4.1 & 12.2 & 2.7 & 1.5 & 1.6 \\
CHF & 2.5 & 0.2 & 0.2 & 0.8 & 0.4 & 0.2 \\
OC & 14.4 & 6.5 & 6.7 & 26.9 & 13.3 & 6.2 \\
& & & & & & \\
\hline
\end{tabular}

Notes: The values refer to the shares of currency holdings in total portfolio holdings (in percent). PE stands for portfolio equity assets, PDL stands for long-term portfolio debt assets, PDS stands for short-term portfolio debt assets. ADV captures advance economies, while EM captures emerging economies. Authors' calculations based on CPIS data. Refer to the Appendix for the list of advanced and emerging countries. 
Table 3: Equity Regressions: Advanced Sample

\begin{tabular}{llllll}
\hline \hline & USD & EUR & GBP & JPY & CHF \\
\hline Imports & 0.200 & 0.556 & 0.164 & -0.229 & 0.360 \\
& $(0.043)^{* * *}$ & $(0.093)^{* * *}$ & $(0.103)$ & $(0.106)^{* *}$ & $(0.066)^{* * *}$ \\
Credit & 0.000 & -0.004 & 0.003 & 0.008 & 0.007 \\
& $(0.001)$ & $(0.001)^{* * *}$ & $(0.002)$ & $(0.003)^{* * *}$ & $(0.002)^{* * *}$ \\
Vol( $\pi)$ & 0.016 & 0.323 & -0.174 & 0.279 & -0.061 \\
& $(0.048)$ & $(0.060)^{* * *}$ & $(0.100)^{*}$ & $(0.120)^{* *}$ & $(0.086)$ \\
Vol(E) & 0.115 & -0.352 & 0.436 & 0.193 & -0.123 \\
& $(0.170)$ & $(0.082)^{* * *}$ & $(0.248)^{*}$ & $(0.739)$ & $(0.214)$ \\
Vol(Q) & 0.022 & -0.001 & -0.188 & -0.108 & 0.117 \\
& $(0.030)$ & $(0.033)$ & $(0.062)^{* * *}$ & $(0.076)$ & $(0.054)^{* * *}$ \\
Correl(Qij) & -0.191 & 0.259 & 0.954 & 0.242 & 0.471 \\
& $(0.219)$ & $(0.263)$ & $(0.453)^{* *}$ & $(0.636)$ & $(0.372)$ \\
EURO & -0.636 & -0.344 & -0.999 & 0.481 & -0.136 \\
& $(0.088)^{* * *}$ & $(0.177)^{*}$ & $(0.230)^{* * *}$ & $(0.365)$ & $(0.208)$ \\
GDP per capita & 0.474 & -0.531 & -0.301 & 1.700 & 1.247 \\
& $(0.123)^{* * *}$ & $(0.143)^{* * *}$ & $(0.264)$ & $(0.367)^{* * *}$ & $(0.225)^{* * *}$ \\
Equity Stock & 0.787 & 0.644 & 0.830 & 1.428 & 0.806 \\
& $(0.047)^{* * *}$ & $(0.056)^{* * *}$ & $(0.085)^{* * *}$ & $(0.092)^{* * *}$ & $(0.065)^{* * *}$ \\
R2 & 0.982 & 0.977 & 0.934 & 0.947 & 0.965 \\
Observations & 132 & 132 & 132 & 118 & 132 \\
& & & & & \\
\hline \hline
\end{tabular}

Notes: The dependent variable is the log of portfolio equity assets denominated in US dollars (USD), euro (EUR), Pound sterling (GBP), Japanese yen (JPY), and Swiss francs $(\mathrm{CHF})$ respectively. $\mathrm{Vol}(\pi)$ pertains to the volatility of domestic inflation, $\mathrm{Vol}(\mathrm{E})$ refers to the volatility of exchange rate, while $\mathrm{Vol}(\mathrm{Q})$ is the volatility of stock returns. Correl (Qij) is the correlation between domestic stock returns and stock returns of country with the reference currency. The regressors are lagged by one period. Equity Stock stands for aggregate equity holdings at the beginning of period. All regressions include time dummies and are estimated with pooled OLS. ${ }^{* * *}, * *$, and ${ }^{*}$ denote significance at $1 \%$, $5 \%$, and $10 \%$ respectively. 
Table 4: Equity Regressions: Emerging Sample

\begin{tabular}{llllll}
\hline \hline & USD & EUR & GBP & JPY & CHF \\
\hline Imports & 0.348 & 0.860 & 0.611 & -0.057 & 0.127 \\
& $(0.064)^{* * *}$ & $(0.133)^{* * *}$ & $(0.183)^{* * *}$ & $(0.113)$ & $(0.115)$ \\
Credit & 0.010 & -0.011 & 0.006 & 0.021 & -0.000 \\
& $(0.003)^{* * *}$ & $(0.004)^{* * *}$ & $(0.005)$ & $(0.006)^{* * *}$ & $(0.004)$ \\
Vol $(\pi)$ & 0.007 & 0.013 & 0.105 & 0.106 & 0.040 \\
& $(0.022)$ & $(0.024)$ & $(0.031)^{* * *}$ & $(0.077)$ & $(0.037)$ \\
Vol(E) & -0.011 & -1.275 & 0.385 & -0.285 & 0.498 \\
& $(0.035)$ & $(0.172)^{* * *}$ & $(0.309)$ & $(0.343)$ & $(0.254)^{*}$ \\
Vol(Q) & -0.117 & 0.024 & 0.048 & -0.067 & 0.013 \\
& $(0.055)^{* *}$ & $(0.061)$ & $(0.138)$ & $(0.182)$ & $(0.075)$ \\
Correl(Qij) & 0.783 & 1.031 & -1.306 & 1.007 & 0.610 \\
& $(0.494)$ & $(0.623)^{*}$ & $(0.770)^{*}$ & $(1.198)$ & $(0.716)$ \\
GDP per capita & 0.834 & 0.433 & -0.048 & -0.372 & -0.263 \\
& $(0.137)^{* * *}$ & $(0.152)^{* * *}$ & $(0.181)$ & $(0.303)$ & $(0.210)$ \\
Equity Stock & 0.598 & 0.869 & 0.915 & 1.367 & 0.897 \\
& $(0.076)^{* * *}$ & $(0.084)^{* * *}$ & $(0.111)^{* * * *}(0.161)^{* * *}$ & $(0.099)^{* * * *}$ \\
R2 & 0.805 & 0.813 & 0.662 & 0.654 & 0.68 \\
Observations & 249 & 215 & 221 & 167 & 169 \\
& & & & & \\
\hline \hline
\end{tabular}

Notes: The dependent variable is the log of portfolio equity assets denominated in US dollars (USD), euro (EUR), Pound sterling (GBP), Japanese yen (JPY), and Swiss francs (CHF) respectively. Vol $(\pi)$ pertains to the volatility of domestic inflation, Vol (E) refers to the volatility of exchange rate, while $\mathrm{Vol}(\mathrm{Q})$ is the volatility of stock returns. Correl (Qij) is the correlation between domestic stock returns and stock returns of country with the reference currency. The regressors are lagged by one period. Equity Stock stands for aggregate equity holdings at the beginning of period. All regressions include time dummies and are estimated with pooled OLS. ***, **, and * denote significance at $1 \%$, $5 \%$, and $10 \%$ respectively. 
Table 5: Debt Regressions: Advanced Sample

\begin{tabular}{|c|c|c|c|c|c|}
\hline & USD & EUR & GBP & JPY & CHF \\
\hline Imports & $\begin{array}{l}0.232 \\
(0.063)^{* * * *}\end{array}$ & 0.012 & 0.414 & -0.406 & $\begin{array}{l}0.708 \\
(0186)^{* * * *}\end{array}$ \\
\hline Credit & $\begin{array}{l}-0.005 \\
(0.001)^{\text {****}}\end{array}$ & $\begin{array}{l}0.005 \\
(0.001)^{* * *}\end{array}$ & $\begin{array}{l}0.003 \\
(0.002)\end{array}$ & $\begin{array}{l}-0.021 \\
(0.004)^{\text {****}}\end{array}$ & $\begin{array}{l}-0.002 \\
(0.004)\end{array}$ \\
\hline $\operatorname{Vol}(\pi)$ & $\begin{array}{l}-0.444 \\
(0.114)^{* * *}\end{array}$ & $\begin{array}{l}-0.136 \\
(0.075)^{*}\end{array}$ & $\begin{array}{l}0.374 \\
(0.218)^{*}\end{array}$ & $\begin{array}{l}-0.277 \\
(0.411)\end{array}$ & $\begin{array}{l}-0.436 \\
(0.401)\end{array}$ \\
\hline $\operatorname{Vol}(\mathrm{E})$ & $\begin{array}{l}-0.030 \\
(0.191)\end{array}$ & $\begin{array}{l}-0.178 \\
(0.070)^{* * *}\end{array}$ & $\begin{array}{l}0.986 \\
(0.307)^{* * *}\end{array}$ & $\begin{array}{l}0.351 \\
(0.504)\end{array}$ & $\begin{array}{l}0.106 \\
(0.530)\end{array}$ \\
\hline $\operatorname{Vol}(Q)$ & $\begin{array}{l}-0.018 \\
(0.038)\end{array}$ & $\begin{array}{l}0.057 \\
(0.025)^{* * *}\end{array}$ & $\begin{array}{l}-0.171 \\
(0.075) * *\end{array}$ & $\begin{array}{l}-0.351 \\
(0171)^{* *}\end{array}$ & $\begin{array}{l}0.319 \\
(0137)^{* * *}\end{array}$ \\
\hline Correl(Qij) & $\begin{array}{l}0.153 \\
(0.089)^{*}\end{array}$ & $\begin{array}{l}0.107 \\
(0.059) *\end{array}$ & $\begin{array}{l}0.392 \\
(0.169)^{* * *}\end{array}$ & $\begin{array}{l}0.402 \\
(0.402)\end{array}$ & $\begin{array}{l}-1.140 \\
(0.346)^{* * * *}\end{array}$ \\
\hline EURO & $\begin{array}{l}-1.519 \\
(0.104)^{* * *}\end{array}$ & $\begin{array}{l}1.139 \\
(0.102) * * *\end{array}$ & $\begin{array}{l}-0.253 \\
(0.209)\end{array}$ & $\begin{array}{l}-1.403 \\
(0.398)^{* * *}\end{array}$ & $\begin{array}{l}0.824 \\
(0.476) *\end{array}$ \\
\hline GDP per capita & $\begin{array}{l}0.378 \\
(0.154)^{* *}\end{array}$ & $\begin{array}{l}0.355 \\
(0.123)^{* * *}\end{array}$ & $\begin{array}{l}1.398 \\
(0.330)^{* * * *}\end{array}$ & $\begin{array}{l}1.547 \\
(0.605)^{* *}\end{array}$ & $\begin{array}{l}4.671 \\
(0.662)^{\text {***** }}\end{array}$ \\
\hline Debt Stock & $\begin{array}{l}0.764 \\
(0.070)^{* * * *}\end{array}$ & $\begin{array}{l}0.832 \\
(0.034)^{* * * *}\end{array}$ & $\begin{array}{l}0.786 \\
(0.089)^{* * * *}\end{array}$ & $\begin{array}{l}1.899 \\
(0.213)^{* * * *}\end{array}$ & $\begin{array}{l}0.632 \\
(0.189)^{\text {****}}\end{array}$ \\
\hline & 0.962 & 0.961 & 0.875 & 0.855 & 0.800 \\
\hline Observations & 141 & 154 & 154 & 129 & 151 \\
\hline
\end{tabular}

Notes: The dependent variable is the log of long-term portfolio debt assets denominated in US dollars (USD), euro (EUR), Pound sterling (GBP), Japanese yen (JPY), and Swiss francs $(\mathrm{CHF})$ respectively. $\operatorname{Vol}(\pi)$ pertains to the volatility of domestic inflation, $\operatorname{Vol}(\mathrm{E})$ refers to the volatility of exchange rate, while $\mathrm{Vol}(\mathrm{Q})$ is the volatility of yields. Correl (Qij) is the correlation between domestic bond yields and bond yields of country with the reference currency. The regressors are lagged by one period. Debt Stock stands for aggregate holdings of long-term debt at the beginning of period. All regressions include time dummies and are estimated with pooled OLS. ${ }^{* * *},{ }^{* *}$, and ${ }^{*}$ denote significance at $1 \%, 5 \%$, and $10 \%$ respectively. 
Table 6: Debt Regressions: Emerging Sample

\begin{tabular}{llllll}
\hline \hline & USD & EUR & GBP & JPY & CHF \\
\hline Imports & 0.300 & 0.425 & 0.447 & 1.143 & 0.592 \\
& $(0.046)^{* * *}$ & $(0.094)^{* * *}$ & $(0.136)^{* * * *}$ & $(0.354)^{* * *}$ & $(0.223)^{* * *}$ \\
Credit & -0.003 & 0.005 & 0.011 & 0.000 & -0.006 \\
& $(0.002)$ & $(0.003)$ & $(0.005)^{* *}$ & $(0.017)$ & $(0.009)$ \\
Vol $(\pi)$ & 0.023 & 0.009 & 0.054 & 0.240 & 0.303 \\
& $(0.017)$ & $(0.025)$ & $(0.066)$ & $(0.166)$ & $(0.134)^{* * *}$ \\
Vol(E) & -0.000 & -0.604 & 0.433 & -0.769 & 0.544 \\
GDP per capita & $(0.027)$ & $(0.112)^{* * *}$ & $(0.296)$ & $(0.754)$ & $(0.354)$ \\
& 0.037 & 0.925 & -0.177 & 0.229 & 1.392 \\
Debt Stock & $(0.112)$ & $(0.168)^{* * *}$ & $(0.221)$ & $(0.727)$ & $(0.514)^{* * *}$ \\
& 1.028 & 0.582 & 0.839 & 1.744 & 0.689 \\
R2 & $(0.047)^{* * *}$ & $(0.067)^{* * *}$ & $(0.101)^{* * *}$ & $(0.451)^{* * *}$ & $(0.235)^{* * *}$ \\
Observations & 0.838 & 0.65 & 0.493 & 0.509 & 0.453 \\
& 257 & 220 & 205 & 115 & 104 \\
\hline \hline
\end{tabular}

Notes: The dependent variable is the log of long-term portfolio debt assets denominated in US dollars (USD), euro (EUR), Pound sterling (GBP), Japanese yen (JPY), and Swiss francs $(\mathrm{CHF})$ respectively. $\mathrm{Vol}(\pi)$ pertains to the volatility of domestic inflation, $\mathrm{Vol}(\mathrm{E})$ refers to the volatility of exchange rate, while $\mathrm{Vol}(\mathrm{Q})$ is the volatility of yields. Correl (Qij) is the correlation between domestic bond yields and bond yields of country with the reference currency. The regressors are lagged by one period. Debt Stock stands for aggregate holdings of long-term debt at the beginning of period. All regressions include time dummies and are estimated with pooled OLS. ${ }^{* * *},{ }^{* *}$, and ${ }^{*}$ denote significance at $1 \%, 5 \%$, and $10 \%$ respectively. 


\section{Appendix: Sample of Countries}

Advanced: Austria, Belgium, Denmark, Finland, France, Germany, Greece, Iceland, Italy, Japan, Netherlands, Portugal, Spain, Sweden, United States

Emerging: Brazil, Bulgaria, Chile, Colombia, Czech Republic, Estonia, Hungary, India, Indonesia, Israel, Kazakhstan, Korea, Kuwait, Latvia, Lithuania, Malaysia, Mexico, Pakistan, Philippines, Poland, Romania, Russia, Slovakia, South Africa, Thailand, Turkey, Ukraine, Uruguay, Venezuela 